\title{
Composição tecidual e química dos cortes comerciais da carcaça de cordeiros Santa Inês terminados em pastagem nativa com suplementação ${ }^{1}$
}

\author{
José Rômulo Soares dos Santos ${ }^{2}$, José Morais Pereira Filho ${ }^{3}$, Aderbal Marcos de Azevêdo \\ Silva $^{3}$, Marcílio Fontes Cezar ${ }^{3}$, Jucileide Barboza Borburema ${ }^{4}$, José Orlando Ramos Silva ${ }^{4}$ \\ 1 Projeto financiado pelo CNPq. \\ 2 Pós-graduando em Zootecnia - UFCG. Rua Nezinho Leandro n42, Bairro Liberdade, Patos - PB, CEP: 58703-100. \\ ${ }^{3}$ Unidade Acadêmica de Medicina Veterinária/CSTR/UFCG. \\ ${ }^{4}$ Curso de graduação em Medicina Veterinária.
}

RESUMO - Objetivou-se com este trabalho avaliar o efeito da suplementação na composição tecidual e química da perna e do lombo de ovinos Santa Inês terminados em pastejo. Foram utilizados 24 ovinos castrados, com peso vivo médio (PV) de 15,8 kg e 3 a 4 meses de idade, distribuídos em três níveis de suplementação com concentrado ( $0 ; 1,0$ e 1,5\% do PV), num delineamento experimental inteiramente casualizado, com três tratamentos e oito repetições. A perna e o lombo foram dissecados em músculo, ossos e gordura, para determinação da composição tecidual, e a carne foi utilizada na determinação da composição química. A suplementação influenciou os rendimentos de músculos, ossos, gordura, matéria seca, cinzas, proteína bruta e gordura do lombo e da perna. A suplementação melhora o rendimento muscular e a composição química do lombo e da perna de ovinos Santa Inês terminados em pastagem nativa. Quando o objetivo for obter carcaças mais leves, o nível de concentrado recomendável é de 1,0\% do PV e, se a finalidade for adquirir carcaças mais pesadas, recomenda-se o nível de 1,5\%.

Palavras-chave: gordura, lombo, músculo, perna, semiárido

\section{Tissue and chemical composition of commercial cuts of carcasses of Santa Inês lambs finished on native pasture with different supplementation levels}

\begin{abstract}
The objective of this study was to evaluate the effects of feed supplementation on the chemical and tissue composition of leg and loin from carcass of Santa Inês lambs, finished on pasture. Twenty-four castrated 3 to 4 month-old Santa Inês lambs were used, initial live body weight (LW) $15.8 \mathrm{~kg}$, distributed in three concentrate supplementation levels (0.0, 1.0 and $1.5 \% \mathrm{LW})$. A randomized complete design was used, with three treatments and eight replications (lambs). The leg and loin were dissected in muscle, bone, fat and to determine tissue composition and the meat was submitted to chemical analyses. The supplementation influenced the yields of loin and leg muscles, bones, fat, dry matter, ash, crude protein and fat. The supplementation improved muscle yield and chemical composition of the loin and leg from Santa Inês lambs finished on native pasture. When the objective is to produce lighter carcasses, the recommended concentrate level is $1.0 \% \mathrm{LW}$, and $1.5 \% \mathrm{LW}$ is recommended to produce heavier carcasses.
\end{abstract}

Key Words: fat, leg, loin, muscle, semi-arid

\section{Introdução}

O consumo de carne ovina no Brasil tem aumentado nos últimos anos, porém não atinge a média per capita de consumo mundial, que é de $2 \mathrm{~kg} /$ pessoa/ano. A média no Nordeste brasileiro é de $0,17 \mathrm{~kg} / \mathrm{hab} / \mathrm{ano}$ e, no Sul do País, é de $1,8 \mathrm{~kg} / \mathrm{pessoa} / \mathrm{ano}$, valores bem inferiores aos $20 \mathrm{~kg} /$ pessoa/ano que são consumidos na Austrália (Roça, 1993).

O mercado de carne ovina no Brasil tende a expandir-se de forma significativa, porém, de acordo com Siqueira et al. (2002), há problemas que se interpõem à expansão dessa atividade, como a qualidade do produto ofertado e a produção, que não atende à demanda de mercado.

Os consumidores contemporâneos exigem um produto com máxima produção da parte comestível (os músculos) e quantidade aceitável de gordura, assim, é necessária a utilização de uma categoria animal capaz de melhorar o direcionamento de nutrientes para a deposição de músculos.

O cordeiro abatido com $30 \mathrm{~kg}$ de peso vivo atende às exigências mercadológicas. Devido aos reduzidos ganhos de peso nos sistemas de produção em pastejo, ovinocultores têm adotado a prática do confinamento para atingir esse 
peso em cordeiros. Todavia, Santello et al. (2006) afirmam que a terminação de cordeiros deve ser feita em sistema de pastejo com suplementação, uma vez que a análise de custos não é favorável ao confinamento.

Com essa perspectiva, a terminação de cordeiros em pastejo com nível adequado de suplementação pode permitir a obtenção de animais com peso vivo e características de carcaça e dos cortes comerciais que atendam as exigências do consumidor.

Embora não exista uma definição dos cortes comerciais no Brasil, Rodrigues et al. (2006) destacam a perna e o lombo como cortes de primeira. Na maioria dos trabalhos, avalia-se composição tecidual e química da perna e/ou do lombo de animais terminados em regime de confinamento, tornando cada vez mais necessário estudar essas composições para determinar se a suplementação para animais terminados em pastejo garante a qualidade do corte e da carne.

Há poucos trabalhos com ovinos deslanados em condições de pastejo no semi-árido, pois a maioria dos pesquisadores avalia raças especializadas na produção de carne (Suffolk, Dorper, etc). Assim, objetivou-se com este trabalho avaliar o efeito da suplementação na composição tecidual da perna e do lombo e na composição química da carne desses cortes em ovinos Santa Inês terminados em pastagem nativa enriquecida com capim-buffel (Cenchrus ciliares L).

\section{Material e Métodos}

O experimento foi conduzido entre os meses de agosto a outubro, na Fazenda "Lameirão", unidade experimental pertencente ao Centro de Saúde e Tecnologia Rural da Universidade Federal de Campina Grande, localizada no município de Santa Teresinha - PB, a 300 m acima do nível do mar.

A área experimental apresenta relevo suavemente ondulado com declividade nunca superior a $10 \%$. Os solos são pobres, de drenagem irregular e pH ácido, classificados como bruno-não-cálcico. O clima da região, segundo a classificação de Köppen, é do tipo BSH'w (quente e seco), caracterizado por duas estações bem definidas, uma chuvosa (janeiro a julho) e outra seca (julho a dezembro). A temperatura anual média máxima é de $32,9^{\circ} \mathrm{C}$ e a mínima de $20,8^{\circ} \mathrm{C}$ e umidade relativa de $61 \%$. A precipitação média anual é de 500 mm (Brasil, 1992).

Foram utilizados 24 ovinos machos da raça Santa Inês, castrados, com peso vivo médio inicial de 15,8 \pm 1,4 kg e idade variando entre 3 e 4 meses, identificados por meio de colar e tatuagem na orelha. Em seguida, em grupos de três foram distribuídos nos níveis de suplementação (0, 1 e 1,5\% do peso vivo em MS). Os animais foram submetidos a um período pré-experimental de 21 dias, com prévia vermifugação e administração $1 \mathrm{~mL}$ de vitaminas ADE (20.000.000 UI de vit. A; 5.000.000 UI de vit. D3 e 5.500 UI de vit. E).

Os animais tinham acesso diariamente à pastagem das 7 às $16 \mathrm{~h}$, quando eram recolhidos para receber a suplementação em baias equipadas com comedouros individuais e bebedouros. As dietas experimentais foram constituídas de pastagem nativa enriquecida com capimbuffel (Cenchrus ciliaris L cv. Biloela) à vontade e níveis crescentes de concentrado.

O concentrado foi à base de milho moído (40,40\%), farelo de soja (56,58 \%) e mistura mineral (3\%), ajustada de modo que a dieta com maior proporção de concentrado atendesse as exigências de proteína bruta (PB) e energia metabolizável (EM), preconizados pelo AFRC (1993) para ganho médio de peso diário de 200 g.

Os ingredientes das rações foram analisados quanto aos teores de matéria seca (MS), proteína bruta (PB), fibra em detergente neutro (FDN), fibra em detergente ácido (FDA), energia bruta (EB) e cinzas de acordo com metodologia descrita por Silva \& Queiroz (2002).

A mistura mineral (Tabela 1) utilizada no concentrado foi constituída de 12,1\% de calcário calcítico; 39\% de fosfato bicálcico; $0,01 \%$ de iodato de potássio; $1 \%$ de sulfato de manganês; $0,5 \%$ de sulfato de zinco; $0,005 \%$ de selenito de sódio; 0,211\% de sulfato de cobre; 0,047\% de sulfato de cobalto; e $47,127 \%$ de sal.

A cada 14 dias os cordeiros foram pesados para controle do desenvolvimento ponderal. Quando o animal do maior

Tabela 1 - Composição química do concentrado utilizado e da forragem disponível na área experimental

\begin{tabular}{|c|c|c|c|c|c|c|}
\hline \multirow[t]{2}{*}{ Ingrediente } & \multirow[t]{2}{*}{ MS (\%) } & \multirow{2}{*}{$\begin{array}{c}\text { Energia bruta } \\
\text { (kcal/kgMS) }\end{array}$} & \multicolumn{4}{|c|}{$\%$ na MS } \\
\hline & & & PB & FDN & FDA & Cinza \\
\hline Farelo de soja & 91,64 & 5310 & 45,96 & 7,90 & 3,82 & 7,27 \\
\hline Fubá de milho & 90,02 & 5670 & 9,73 & 9,00 & 4,01 & 6,02 \\
\hline Gramíneas $^{1}$ & 66,54 & 4479 & 4,08 & 79,27 & 49,32 & 7,30 \\
\hline Gramíneas ${ }^{2}$ & 66,35 & 4493 & 2,80 & 80,79 & 52,71 & 7,66 \\
\hline Dicotiledôneas $^{1}$ & 50,63 & 4418 & 9,22 & 68,31 & 45,75 & 6,70 \\
\hline Dicotiledôneas ${ }^{2}$ & 68,54 & 4633 & 3,76 & 77,47 & 54,50 & 3,64 \\
\hline
\end{tabular}

${ }^{1}$ Início do experimento; ${ }^{2}$ final do experimento. 
nível de suplementação de cada grupo atingia $30 \mathrm{~kg}$ de peso vivo, era abatido juntamente com seus pares. Antes do abate, os animais eram submetidos a jejum de sólidos de 16 horas e de líquidos de 14 horas. Os animais foram abatidos mediante atordoamento e sangria, feita por um corte nas artérias carótida comum direita e esquerda e nas veias jugulares externas.

Após a sangria, a pele foi retirada e foram feitas a evisceração, a retirada de cabeça e da cauda, e seccionados os membros anteriores e posteriores a partir das articulações carpo-metacarpiana e tarso-metatarsiana, respectivamente, obtendo-se a carcaça, que foi levada para câmara fria com temperatura de $5^{\circ} \mathrm{C}$ por um período de 24 horas. As carcaças foram seccionadas longitudinalmente ao meio utilizando-se serra elétrica (Boggs et al., 1998). Das meias-carcaças esquerdas foram separados dois cortes comerciais: lombo e perna, que então foram congelados a $-20^{\circ} \mathrm{C}$ para posterior dissecação. A base óssea e a região de secção dos cortes selecionados na meia-carcaça esquerda estão de acordo com metodologia descrita por Osório et al. (1998).

A dissecação dos cortes comerciais foi feita em sala climatizada e adaptada para essa finalidade, onde os cortes comerciais eram descongelados, pesados e dissecados em músculo, osso, gordura subcutânea e gordura intermuscular. Essas gorduras foram somadas para quantificar o total de gordura dos cortes (Osório et al., 1998). Os resultados foram expressos em peso absoluto e em relação à participação percentual de cada componente tecidual em relação ao peso do respectivo corte. Também foram determinadas as relações entre peso dos músculos e peso da gordura total, bem como a relação peso dos músculos e peso dos ossos de cada corte.

Para determinação da composição química de cada corte, foram separados os principais músculos a fim de comporem amostra de carne: do lombo foi separado o músculo longissimus lumborum (longuíssimo lombar) e da perna foram dissecados os músculos: semitendinoso, semimembranoso, adutor, glúteo bíceps e quadríceps femural.

A carne de cada corte foi triturada e homogeneizada para retirada de uma amostra que foi utilizada para determinação da matéria seca (MS), da gordura (extrato etéreo - EE), da proteína bruta (PB) em aparelhos semimicro Kjeldahl e da matéria mineral, todos conforme metodologias descritas por Silva \& Queiroz (2002).

O delineamento experimental foi inteiramente casualizado, com três tratamentos (níveis de suplementação) e oito repetições. Os dados foram submetidos à análise de variância e, quando pertinente, as médias foram comparadas pelo teste Tukey. Todas as análises foram desenvolvidas com 5\% de probabilidade, e foram realizadas por meio dos procedimentos Proc Glm do SAS (1999), adotando-se o seguinte modelo estatístico: $\mathrm{Y}_{\mathrm{ij}}=\mu+\mathrm{S}_{\mathrm{i}}+\mathrm{E}_{\mathrm{ij}}$, em que $\mathrm{Y}_{\mathrm{ij}}=$ valor observado para a característica analisada; $\mu=$ média geral; $\mathrm{S}_{\mathrm{i}}=$ efeito da suplementação $\mathrm{i}$, com $\mathrm{i}$ variando de 1 a $3 ; \mathrm{E}_{\mathrm{ij}}=$ erro experimental

\section{Resultados e Discussão}

O ganho de peso médio diário e o peso ao abate foram, respectivamente, de: $77 \mathrm{~g} /$ dia e 20,54 $\pm 2,24 \mathrm{~kg}$ para os animais que receberam $0 \%$ de suplementação; $134 \mathrm{~g} / \mathrm{dia}$ e $23,63 \pm 2,42 \mathrm{~kg}$ para os animais que receberam 1,0\% de suplementação; 190 g/dia e 27,09 $\pm 2,27$ kg para os ovinos que receberam $1,5 \%$ de suplementação.

Os níveis de suplementação não promoveram diferença $(\mathrm{P}>0,05)$ no peso dos ossos, da gordura total, da gordura subcutânea, para a proporção de gordura total, de gordura subcutânea, de gordura intermuscular e para a RMG (Tabela 2). Houve efeito de suplementação $(\mathrm{P}<0,05)$ no peso dos músculos. Não se detectou significância $(\mathrm{P}>0,05)$ para peso da gordura intermuscular e proporção dos músculos e dos ossos do lombo nos níveis de suplementação 1,0 e $1,5 \%$, porém ambos diferiram $(\mathrm{P}<0,05)$ do observado sem suplementação. A relação músculo:osso diferiu entre os níveis de suplementação 0 e 1,5\%, mas não houve significância $(\mathrm{P}>0,05)$ em relação à suplementação de $1,0 \%$.

Os níveis de suplementação 0,0; 1,0 e 1,5\% promoveram diferençla nos pesos dos músculos do lombo, todavia não houve diferença significativa entre 1,0 e 1,5\% para o rendimento muscular, o que permitiu a obtenção de rendimento muscular semelhante com menor custo, uma vez que o nível de suplementação 1,5\% aumenta em 50\% o concentrado. $\mathrm{O}$ mesmo pode ser aplicado para o peso dos ossos de cada corte, considerando que o nível de $1 \%$ promoveu valores intermediários.

Furusho-Garcia et al. (2003) trabalharam com ovinos Santa Inês puros abatidos aos 180 dias depois de confinamento recebendo silagem de capim-napier com casca de café e obtiveram pesos de gordura de $103 \mathrm{~g}$, equivalentes a 16,32\% do lombo, 362 g de músculo, equivalentes a $57,37 \%$. Os pesos foram superiores aos registrados neste experimento com 1,5\% de suplementação. O rendimento muscular de 58,96 e $61,11 \%$ obtido nos animais que receberam concentrado na quantidade de 1,0 e 1,5\% do PV pode ser considerado próximos aos valores obtidos por esses autores, mas, em termos de gordura, os valores para os três níveis de suplementação foram menores. Mesmo sendo abatidos com idade inferior à dos animais 
deste experimento (em torno de 210 dias), o confinamento influenciou diretamente. Diaz et al. (2002) afirmam que cordeiros terminados em pastejo geralmente têm menos gordura e apresentam maiores exigências de energia, em decorrência do aumento do metabolismo basal associado à atividade do pastejo.

Os maiores valores obtidos para gordura subcutânea e intramuscular neste experimento foram 40,44 g e 15,12 g para o nível de suplementação de 1,5\%. Resultados superiores aos 38,05 g de gordura subcutânea e inferiores aos 38,37 g de gordura intermuscular obtidos por Almeida Jr. et al. (2004) para cordeiros não-castrados da raça Suffolk mantidos em creep feeding e abatidos com $28 \mathrm{~kg}$ de PV. Os animais Suffolk foram abatidos com PV inferior, mas, em virtude de sua aptidão para produção de carne, depositaram mais gordura. Embora não tenha ocorrido diferença $(\mathrm{P}>0,05)$ para peso e rendimentos da gordura subcutânea entre os níveis de suplementação, na ausência de suplementação, o peso absoluto da gordura subcutânea foi de 27,87 g, representando 9,58\% do lombo, enquanto, no nível de suplementação $1,5 \%$, o peso foi de $40,44 \mathrm{~g}$, representando apenas $8,57 \%$ do lombo, o que comprova a real necessidade de avaliação dos tecidos, sobretudo gordura, que depende da idade, da nutrição e do peso de abate. A variação na taxa de deposição de músculo e de gordura pode determinar, em determinado momento, rendimento maior de gordura para animais mais leves que para animais mais pesados.

Outro aspecto a ser destacado é o rendimento inferior da gordura intermuscular em relação à gordura subcutânea, o que era esperado, uma vez que o espaço intermuscular é menor que o subcutâneo (Pinheiro et al., 2007).

Os resultados obtidos para músculo e gordura indicam a necessidade de suplementação e que níveis entre 1,0 e 1,5\% do PV em concentrado possibilitam melhora no desenvolvimento muscular do lombo sem aumentar a proporção de gordura em relação aos animais em pastejo, o que tem papel decisivo no comportamento da maioria dos agentes da cadeia produtiva, visto que a gordura é um tecido de deposição tardia e que ocorre com elevado consumo de energia (Huidobro \& Cañeque, 1994), o que torna os custos com alimentação/produção elevados, em decorrência do preço do concentrado.

Não houve significância $(\mathrm{P}>0,05)$ entre os níveis de suplementação 1,0 e 1,5\% para matéria seca (MS) e proteína bruta (PB) da carne do lombo, mas ambos os níveis melhoraram os teores de MS e PB em comparação à ausência de suplementação (Tabela 3). Esses resultados podem estar relacionados ao ganho de peso diário desses animais (77 g) em relação aos 134 e 190 g observados nos animais com 1,0 e $1,5 \%$ de suplementação. Neste caso, a ausência da

Tabela 2 - Médias e coeficientes de variação (CV) do peso e rendimento dos tecidos, das relações entre o peso da gordura total e o peso dos ossos do lombo de ovinos Santa Inês terminados em pastagem nativa e submetidos a diferentes níveis de suplementação

\begin{tabular}{|c|c|c|c|c|}
\hline \multirow[t]{2}{*}{ Item } & \multicolumn{3}{|c|}{ Nível de suplementação (\% do PV) } & \multirow[t]{2}{*}{ CV (\%) } \\
\hline & 0 & 1,0 & 1,5 & \\
\hline Lombo (g) & $297,04 b$ & $359,21 b$ & $456,22 a$ & 18,32 \\
\hline Músculos (g) & $145,48 c$ & $210,90 b$ & $276,86 a$ & 18,94 \\
\hline Ossos (g) & $118,29 a$ & $106,74 \mathrm{a}$ & $123,79 a$ & 28,32 \\
\hline Gordura total (g) & 33,26a & $41,57 a$ & $55,56 a$ & 48,04 \\
\hline Gordura subcutânea (g) & $27,87 \mathrm{a}$ & $30,92 \mathrm{a}$ & $40,44 \mathrm{a}$ & 56,17 \\
\hline Gordura intermuscular (g) & $5,39 b$ & $10,64 \mathrm{a}$ & $15,12 \mathrm{a}$ & 37,21 \\
\hline Músculos (\%) & 48,95b & $58,96 a$ & $61,11 \mathrm{a}$ & 10,35 \\
\hline Ossos $(\%)$ & $39,64 a$ & $29,47 b$ & 26,99b & 19,18 \\
\hline Gordura total (\%) & $11,41 \mathrm{a}$ & $11,57 \mathrm{a}$ & $11,89 a$ & 40,45 \\
\hline Gordura subcutânea (\%) & $9,58 a$ & $8,47 a$ & $8,57 \mathrm{a}$ & 46,29 \\
\hline Gordura intermuscular (\%) & $1,83 a$ & $3,10 \mathrm{a}$ & 3,33a & 43,49 \\
\hline RMG (g/g) & $5,04 a$ & $5,60 \mathrm{a}$ & $5,87 a$ & 38,88 \\
\hline RMO (g/g) & $1,24 b$ & $2,21 \mathrm{ab}$ & $2,51 \mathrm{a}$ & 45,16 \\
\hline
\end{tabular}

Médias seguidas de letras diferentes na mesma linha diferem significativamente pelo teste Tukey 5\%.

Tabela 3 - Médias e coeficientes de variação (CV) de matéria seca, cinzas, proteína bruta e gordura da carne do lombo de ovinos Santa Inês terminados em pastagem nativa com suplementação

\begin{tabular}{|c|c|c|c|c|}
\hline \multirow[t]{2}{*}{ Item } & \multicolumn{3}{|c|}{ Nível de suplementação (\% do PV) } & \multirow[t]{2}{*}{ CV (\%) } \\
\hline & 0 & 1,0 & 1,5 & \\
\hline Matéria seca (\%) & $20,42 b$ & $23,89 a$ & $25,06 a$ & 6,40 \\
\hline Cinzas (\%) & $0,80 \mathrm{~b}$ & $0,84 b$ & $1,21 \mathrm{a}$ & 22,56 \\
\hline Proteína bruta (\%) & $17,98 b$ & $22,09 a$ & $22,54 \mathrm{a}$ & 8,40 \\
\hline Gordura (\%) & $0,62 \mathrm{~b}$ & $1,37 \mathrm{ab}$ & $2,06 a$ & 44,21 \\
\hline
\end{tabular}

Médias seguidas de letras diferentes na mesma linha diferem significativamente pelo teste Tukey 5\%. 
suplementação não permitiu que o organismo atingisse o máximo de deposição de massa muscular, principalmente no lombo, que é um corte de crescimento tardio.

Os teores de matéria seca (25,06 \%) e gordura (2,06\%) obtidos no nível de 1,5\% foi próximo aos de 25,4 e 2,39\% obtidos por Almeida Jr. et al. (2004) ao trabalharem com cordeiros Suffolk mantidos em pasto com grama estrela com suplementação em creep feeding à base de 100\% de grãos de milho úmido, apresentando $21 \%$ de PB e abatidos com PV de $28 \mathrm{~kg}$. A similaridade no teor de MS deve-se provavelmente à semelhança no teor de gordura entre este trabalho, no nível de suplementação 1,5\% (2,06\%) com o obtido por Almeida Jr. et al. (2004), 2,39\%, uma vez que, à medida que o teor de gordura aumenta, também aumenta o teor de matéria seca. Valor semelhante aos obtidos neste experimento para os animais com suplementação 1,0 e 1,5\% foi observado por Almeida Jr. et al. (2004), de 21,15\%, no músculo longissimus lumborum. Normalmente o teor de proteína nas carnes ovinas é o que menos varia, o que não ocorreu neste experimento, em virtude do consumo de matéria seca e de proteína do concentrado, imposto pelos tratamentos, fato também destacado por Gonzaga Neto et al. (2005) em trabalho sobre as exigências nutricionais de ovinos Morada Nova.

Os valores de matéria mineral (MM) do lombo para os níveis de suplementação 0 e 1,0\% foram semelhantes, porém inferiores ao obtido em $1,5 \%$ de suplementação. Os valores de MM na carne variam pouco, mesmo em trabalhos com confinamento. Priolo et al. (2005), ao trabalharem com cordeiros Comisana, na Itália, abatidos com PV de 20,6 kg e idade de 148 dias, depois de confinamento, obtiveram 1,3\% de cinzas, valor próximo aos obtidos neste experimento.

O músculo e a gordura intramuscular não se desenvolvem de forma isométrica, e apresentam impulso de crescimento em fase distinta da vida do animal. O tecido muscular e a proteína têm máximo desenvolvimento em idade intermediária e o tecido adiposo em idade mais tardia com redução do teor de umidade e aumento do teor de MS. A gordura da carne do lombo no tratamento $0 \%$ foi de $0,62 \%$, inferior aos $2,06 \%$ do $1,5 \%$, mas não houve significância $(\mathrm{P}>0,05)$ em relação ao $1,37 \%$ obtidos para o nível de suplementação 1\%. Almeida Jr. et al. (2004) obtiveram, com cordeiros Suffolk abatidos com PV de $28 \mathrm{~kg}$, no músculo longissimus lumborum: 2,39\% de gordura, valor superior ao obtido com o maior nível de suplementação deste experimento, refletindo, segundo Madruga et al. (2006), a maior capaci-dade de raças de corte como Suffolk para produção de carne e deposição de gordura na carcaça e na carne.

Os níveis de suplementação não influenciaram ( $\mathrm{P}>0,05)$ o rendimento da gordura subcutânea (Tabela 4), todavia ocasionaram alto coeficiente de variação (42,58\%). O peso dos ossos foi igual $(\mathrm{P}>0,05)$ nos níveis 0 e $1,0 \%$, ambos diferindo $(\mathrm{P}<0,05)$ do nível $1,5 \%$ de suplementação. Os pesos das gorduras total e intermuscular difereriam $(\mathrm{P}<0,05)$ entre todos os níveis de suplementação. Os níveis de suplementação 1,0 e 1,5\% promoveram, respectiva mente, duas $(66,89 \mathrm{~g})$ e quase três vezes $(98,56)$ o valor de gordura total em relação aos animais com $0 \%$ de suplementação. Em relação ao nível de suplementação 0\%, os níveis 1,0 e $1,5 \%$ de suplementação obtiveram 25,05 e $39,39 \mathrm{~g}$ correspondendo ao dobro e quase quatro vezes a quantidade de gordura intermuscular.

O peso da gordura subcutânea e o rendimento da gordura total da perna diferiram entre os níveis 0 e $1,5 \%$ de suplementação, mas o nível 1,0\% foi intermediário e semelhante aos demais. Não houve diferença $(P>0,05)$ entre os níveis 1,0 e 1,5\% de suplementação para peso dos

Tabela 4 - Médias e coeficientes de variação (CV) do peso e do rendimento dos tecidos, das relações músculo:gordura e músculo:osso da perna de ovinos Santa Inês terminados em pastagem nativa com suplementação

\begin{tabular}{|c|c|c|c|c|}
\hline \multirow[t]{2}{*}{ Item } & \multicolumn{3}{|c|}{ Nível de suplementação (\% do PV) } & \multirow[t]{2}{*}{$\mathrm{CV}(\%)$} \\
\hline & 0 & 1,0 & 1,5 & \\
\hline Perna (g) & $1009,37 c$ & $1292,29 b$ & $1548,31 \mathrm{a}$ & 11,00 \\
\hline Músculos (g) & $669,20 b$ & $912,24 a$ & $1064,52 \mathrm{a}$ & 14,49 \\
\hline Gordura total (g) & $33,05 c$ & $66,89 b$ & $98,56 a$ & 35,53 \\
\hline Gordura subcutânea (g) & $22,90 b$ & $41,88 a b$ & $59,17 \mathrm{a}$ & 47,44 \\
\hline Gordura intermuscular (g) & $10,15 c$ & $25,01 b$ & $39,39 a$ & 33,49 \\
\hline Gordura total (\%) & $3,27 b$ & $5,11 \mathrm{ab}$ & 6,39a & 31,01 \\
\hline Gordura subcutânea (\%) & $2,30 \mathrm{a}$ & $3,19 \mathrm{a}$ & $3,86 a$ & 42,58 \\
\hline Gordura intermuscular (\%) & $0,98 b$ & $1,92 \mathrm{a}$ & $2,54 a$ & 27,69 \\
\hline RMG (g/g) & $20,62 \mathrm{a}$ & $14,75 b$ & $11,72 b$ & 22,88 \\
\hline RMO (g/g) & $2,19 b$ & $2,91 \mathrm{a}$ & $2,80 \mathrm{a}$ & 15,17 \\
\hline
\end{tabular}

Médias seguidas de letras diferentes na mesma linha diferem significativamente pelo teste Tukey 5\%. 
músculos da perna, a proporção de gordura intermuscular e de ossos, a relação músculo:gordura e a relação músculo:osso, porém ambos diferiram $(\mathrm{P}<0,05)$ em relação ao nível $0 \%$. Os músculos, proporcionalmente, mostraram diferença entre os níveis 0 e $1,0 \%$ de suplementação, ambos não diferiram do nível 1,5\%. Nestas circunstâncias o nível de $1 \%$ é a melhor opção, por tornar a relação músculo:gordura menos onerosa.

Considerando que os níveis de suplementação promoveram melhores valores para peso e rendimento muscular da perna, diferindo estatisticamente dos animais sem suplementação, e que, mesmo que a gordura total tenha apresentado maior deposição no nível de suplementação 1,5 \%, a relação músculo:gordura foi similar entre 1,0 e 1,5\% de suplementação. Nessas circunstâncias, opta-se pelo nível de 1,0 \% de suplementação, uma vez que aumento de $50 \%$ onera mais a produção. Os concentrados representam maior gasto na produção e, quanto mais se economizar maximizando a produção de músculo com uma quantidade adequada de gordura e uma suplementação mínima concentrada, melhor se tornará a relação custo/beneficio.

Os maiores valores de peso da gordura subcutânea e intermuscular dos ovinos Santa Inês obtidos no tratamento com 1,5\% corroboram a opinião de Huidobro \& Cañeque (1994) de que, quanto maior a densidade energética, maior a deposição de gordura.

A participação dos músculos e da gordura aumentou com a suplementação, destacando-se a proporção de músculo no nível de $1,0 \%$ e a de gordura no nível de $1,5 \%$, refletindo na relação direta com o consumo de energia, confirma a opinião de Garcia et al (2003). Um fato interessante é que a gordura subcutânea, embora maior em valor absoluto no nível de 1,5\% de suplementação, não sofreu influência significativa, enquanto o rendimento da gordura intermuscular sofreu influência da dieta e determinou variação estatística no rendimento de gordura total.

Velasco et al. (2004) trabalharam com ovinos Talaverana em pastejo na Espanha utilizando suplementação concentrada e, ao abaterem animais com $28 \mathrm{~kg}$ de PV, obtiveram 7,33 para relação músculo:gordura, valor maior ao obtido neste experimento, ocasionado pelo peso ao abate, que foi inferior e ocasionou menor deposição de tecido adiposo. Animais em pastejo geralmente têm relação músculo:gordura maior que a daqueles em confinamento, pois, de acordo com Butterfield (1988), atividade de pastejo está relacionada a maior gasto energético e menor deposição de gordura.

A matéria seca e a gordura dos músculos da perna não diferiram estatisticamente $(\mathrm{P}>0,05)$ entre os níveis de 1,0 e 1,5\% de suplementação, porém ambos diferiram do tratamento 0\% (Tabela 5). À medida que a gordura aumenta, o teor de umidade na carne diminui e o teor de matéria seca aumenta, como o nível de suplementação 1 e 1,5\% promoveram efeito sobre a gordura em relação à carne dos animais não suplementados a matéria seca também sofreu influência.

A matéria mineral e a proteína bruta dos músculos da perna diferiram entre os níveis de suplementação 0 e 1,5\%, mas ambos não diferiram em relação ao nível $1 \%$. Confirma-se, ainda, a premissa de que a proteína é um dos componentes que menos varia na carne e no corpo de ovinos (Gonzaga Neto et al., 2005).

Hoffman et al. (2003) trabalharam com ovinos meiosangue Suffolk-Merino, na África do Sul, em pastejo, abatidos com 40 kg PV, e obtiveram a seguinte composição centesimal do músculo semimembranoso: 34,65\% de matéria seca, $18,45 \%$ de proteína bruta, $16,11 \%$ de gordura e de $1,04 \%$ de cinzas. Os valores de MS e gordura foram superiores aos obtidos neste experimento com ovinos Santa Inês sob suplementação com 0, 1,0 e 1,5\% e abatidos aos 20,54; 23,63 e 27,09 kg de peso vivo, o que contrasta com os $40 \mathrm{~kg}$ dos ovinos F1 (suffolk $\times$ Merino), que, por sua vez, depositam mais tecido adiposo.

O músculo é o tecido de maior apreciação pelo consumidor e seu maior componente orgânico é a proteína, todavia é necessária adequada deposição de músculo e que não repercuta dispendiosidade, considerando que é resultado de maior consumo energético, decorrente de maior ingestão de concentrado. Neste experimento o aumento dos níveis de suplementação dos ovinos

Tabela 5 - Médias e coeficientes de variação (CV) de matéria seca, cinzas, proteína bruta e gordura da carne da perna de ovinos Santa Inês terminados em pastagem nativa e submetidos a diferentes níveis de suplementação

\begin{tabular}{lcccc}
\hline \multirow{2}{*}{ Item } & \multicolumn{3}{c}{ Nível de suplementação (\% do PV) } & \multicolumn{2}{c}{ CV (\%) } \\
\cline { 2 - 4 } & 0 & 1,0 & 1,5 & \\
\hline Matéria seca (\%) & $20,58 \mathrm{~b}$ & $22,02 \mathrm{a}$ & $22,24 \mathrm{a}$ & 4,74 \\
Cinzas (\%) & $1,16 \mathrm{~b}$ & $1,2 \mathrm{ab}$ & $1,56 \mathrm{a}$ & 23,67 \\
Proteína bruta (\%) & $18,50 \mathrm{~b}$ & $19,04 \mathrm{ab}$ & $19,98 \mathrm{a}$ & 5,15 \\
Gordura (\%) & $0,97 \mathrm{~b}$ & $1,9 \mathrm{a}$ & $1,58 \mathrm{a}$ & 24,56 \\
\hline
\end{tabular}

Médias seguidas de letras diferentes na mesma linha diferem significativamente pelo teste Tukey 5\%. 
terminados em pastagem nativa não foi capaz de produzir carnes gordas, pois os valores registrados para gordura na carne não passaram de 5\%, valor de acordo com Gutler et al. (1987) considerado para carnes magras.

\section{Conclusões}

A suplementação melhora o rendimento muscular e a composição química do lombo e da perna de ovinos Santa Inês terminados em pastagem nativa. Considerando os resultados para rendimento de gordura total e os pesos de gordura e ossos de cada corte, os teores de matéria seca, cinzas, proteína e gordura, recomenda-se suplementação com concentrado em níveis de 1,0 a 1,5\% do peso vivo.

\section{Literatura Citada}

AGRICULTURAL AND FOOD RESEARCH COUNCIL - AFRC. Technical Committee on Responses to Nutrients. Energy and protein requirements of ruminants. Wallingford: CAB International, 1993. 151p.

ALMEIDA JR., G.A; COSTA, C.; MONTEIRO, A.L.G. et al. Qualidade da carne de cordeiros, criados em creep feeding com silagem de grãos úmidos de milho. Revista Brasileira de Zootecnia, v.33, n.4, p.1039-1047, 2004.

BOGGS, D.L.; MERKEL, R.A.; DOUMIT, M.E. Livestock and carcasses. An integrated approach to evaluation, grading and selection. Kendall: Hunt Publishing Company, 1998. 259p.

BRASIL. Secretaria Nacional de Irrigação. Departamento Nacional de Meteorologia. Normas climatológicas: 1961-1990. Brasília: EMBRAPA-SPI, 1992. 84p.

BUTTERFIELD, R. New concept of sheep growth. Sydney: Sydney University Press, 1988. 167p.

DIAZ, M.T.; VELASCO, S.; CAÑEQUE, V. et al. Use of concentrate or pasture for fattening lambs and its effect on carcass and meat quality. Small Ruminant Research, v.43, p.257-268, 2002.

FURUSHO-GARCIA, I.F.; PEREZ, J.R.O.; TEIXEIXA, J.C. Componentes de carcaça e composição de alguns cortes de cordeiros Texel x Bergamácia, Texel x Santa Inês e Santa Inês puros terminados em confinamento, com casca de café como parte da dieta. Revista Brasileira de Zootecnia, v.32, n.6, p.1999-2006, 2003 (supl. 2).

GARCIA, C.A.; MONTEIRO, A.L.G.; COSTA, C. et al. Medidas objetivas e composição tecidual da carcaça de cordeiros alimentados com diferentes níveis de energia em creep feeding. Revista Brasileira de Zootecnia, v.32, n.6, p.1380-1390, 2003.
GONZAGA NETO, S.; SILVA SOBRINHO, A.; RESENDE, K.T. et al. Composição corporal e exigências nutricionais de proteína e energia para cordeiros Morada Nova. Revista Brasileira de Zootecnia, v.34, n.6, p.2446-2456, 2005 (supl.).

GUTLER, H.; KETZ, A.; KOLB, E. et al. Kolb: Fisiologia veterinária. 4.ed. Rio de Janeiro: Guanabara Koogan, 1987. $612 \mathrm{p}$.

HOFFMAN, L.C.; MUller, M.; ClOete, S.W.P. et al. Comparison of six crossbred lamb types: sensory, physical and nutritional meat quality characteristics. Meat Science, v.65, p.1265-1274, 2003.

HUIDOBRO, F.R.; CAÑEQUE, V. Producción de carne de corderos de raza Manchega. 5. Crescimento relativo del quarto y de los tejidos y piezas e la canal. Investigación y Sanidad Animales, n.2, v.9, p.95-108, 1994.

MADRUGA, M.S.; ARAUJO, W.O.; SOUSA, W.H. et al. Efeito do genótipo e do sexo sobre a composição química e o perfil de ácidos graxos da carne de cordeiros. Revista Brasileira de Zootecnia, v.35, n.4, p.1838-1844, 2006.

OSÓRIO, J.C.S.; OSÓRIO, M.T.M.; JARDIM, P.O. et al. Métodos para avaliação da produção da carne ovina: "in vivo", na carcaça e na carne. Pelotas: UFPEL, 1998. 107p.

PINHEIRO, R.S.B.; SILVA SOBRINHO, A.G.; YAMAMOTO, S.M. et al. Composição tecidual dos cortes da carcaça de ovinos jovens e adultos. Pesquisa Agropecuária Brasileira, v.42, n.4, p.565-571, 2007.

PRIOLO, A.; BELLA, M.; LANZA, M. et al. Carcass and meat quality of lambs fed fresh sulla (Heddysaarum coronariium L.) with or without polyethylene glicol or concentrate. Small Ruminant Research, v.59, p.281-288, 2005.

ROÇA, R.O. Alternativas de aproveitamento da carne ovina. Revista Nacional da Carne, n.201, p.53-60, 1993.

RODRIGUES, S.; CADAVEZ, V.; TEIXEIRA, A. Breed and maturity effects on Churra Galega Bragançana and Suffolk lamb carcass characteristics: killing-out proportion and composition. Small Ruminant Research, v.72, p.288-293, 2006.

SANTELLO, G.A.; MACEDO, F.A.F.; MEXIA, A.A. et al. Características de carcaça e análise do custo de sistemas de produção de cordeiros $1 \frac{1}{2}$ Dorset Santa Inês. Revista Brasileira de Zootecnia, v.35, n.4, p.1852-1859, 2006 (supl. 2).

SILVA, D.J.; QUEIROZ, A.C. Análise de alimentos: métodos químicos e biológicos. 3.ed. Viçosa, MG: Universidade Federal de Viçosa, 2002. 235p.

SIQUEIRA, E.R.; ROÇA, R.Q.; FERNANDES, S. et al. Características sensoriais da carne de cordeiros das raças Hampshire Down, Santa Inês e mestiços Bergamácia x Corriedale, abatidos com quatro distintos pesos. Revista Brasileira de Zootecnia, v.31, n.3, p.1269-1272, 2002.

STATISTICAL ANALYSIS SYSTEM - SAS. User's guide. Cary: SAS Institute, 1999. 842p.

VELASCO, S.; CAÑEQUE, V.; LAUZURICA, S. et al. Effect of different feeds on meat quality and fatty acid composition of lambs fattened at pasture. Meat Science, v.66, p.457-465, 2004. 